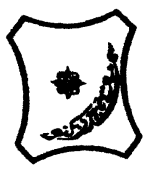

Bayero Journal of Pure and Applied Sciences, 12(2): 81 - 88

Received: June, 2019

Accepted: October, 2019

ISSN $2006-6996$

\title{
EVALUATION OF NUTRITIONAL QUALITY AND MINERAL COMPOSITION OF FERMENTED MILK (NONO) SOLD IN KANO, NORTH-WESTERN NIGERIA
}

*Omola, E.M., Kawo, A.H. and Bukar, A.

Department of Microbiology, Faculty of Life Sciences, College of Natural and Pharmaceutical Sciences, Bayero University, PMB 3011, Kano, Nigeria.

* Correspondence author: omolamichael@yahoo.com; +2348065464463

ABSTRACT

Nono is produced traditionally by spontaneous fermentation in homes, especially in villages where the safety of the product is not considered and due to the increasing environmental pollution, toxic elements may find their way into the food chain which may create significant health concerns. This study therefore, was conducted to evaluate the nutritional quality and mineral composition of nono milk sold in Kano, North-Western Nigeria using standard procedures. The physical and nutritional characteristics including protein, carbohydrate, ash, moisture, fat and total solids were determined using the method of the Association of Official Analytical Chemists while the elemental content was determined using flame atomic absorption spectroscopy analytic method. The mean protein content ranged from 2.90 to $7.0 \%$, carbohydrate $4.60-8.20 \%$, ash content $0.50-0.85 \%$, moisture content 79.82 $87.0 \%$, fat content $2.90-4.66 \%$ and total solid $8.60-12.43 \%$. The values of protein content and that of carbohydrate obtained in this study exceeded the FAO standard. The mean sodium content ranged from 2.22 - $3.28 \mathrm{mg} / \mathrm{l}$, potassium $(0.86-2.65 \mathrm{mg} / \mathrm{l})$, magnesium (3.95 - 6.30 mg/I), calcium (39.85 - 59.07mg/I), iron (1.23 - $4.53 \mathrm{mg} / \mathrm{I})$, copper $(0.61-1.28 \mathrm{mg} / \mathrm{I})$, zinc $(0.43-0.64 \mathrm{mg} / \mathrm{I})$, cadmium $(0.00-0.03 \mathrm{mg} / \mathrm{I})$, chromium $(0.78-$ $1.58 \mathrm{mg} / \mathrm{I})$ and lead $(0.00-1.07 \mathrm{mg} / \mathrm{I})$.. The value of lead observed in Dawakin tofa is significantly higher than other markets and this constitutes serious risk to public health. It is recommended that studies on preservation methods should be carried out as it affects nono production.

Key words: Fermented milk, Kano, Mineral element, Nono, Nutritional quality

\section{INTRODUCTION}

During Neolithic age, farmers out of desperation and starvation depended on cow's milk for nourishment (Valente, 2017). Milking cows brought about the domestication of cattle and the production of milk provided a constant source of nourishment for early farmers, and it grew to other products (Valente, 2017). Nono is a Nigerian locally-fermented milk product commonly prepared through subsistence level by the Fulani cattle rearers. It is produced from non-pasteurized cow milk collected in a container called kwarya (calabash) and allowed to ferment naturally for 24 hours (Obadina et al., 2013). During the production process, fraudulent practices are carried out such as addition of stream water and colorant to increase the volume of the product (Yahuza, 2001). Milk is contaminated with heavy metals such as zinc, lead, cadmium, selenium, sulphur, iodine and possibly even more dangerous arsenic and cyanide (Nasr et al., 2007). The hard metals are released into the environment from natural as well as human activities (Abdulkhaliq et al., 2012). Essential metals such as iron, copper, magnesium and zinc which are required by humans in trace amount to maintain proper metabolic activity may be present in nono milk, others like lead and cadmium that have no biological role to play may also be found (Farid et al., 2004). Their potential toxicity to humans and animals is a source of concern. Increase in industrial and agricultural processes have resulted in increased concentration of metals in the air, water and soil. These metals are taken in by plants and consequently accumulate in their tissues. Animals that graze on such contaminated plants and drink from polluted waters also accumulate such metals in their tissues and milk if lactating (Yahaya et al., 2010). A large amount of these metals taken in by plants and animals subsequently find their way into the food chain. 
BAJOPAS Volume 12 Number 2, December, 2019

Due to this growing environmental pollution it is necessary to determine and monitor the levels of heavy metals in milk, because they can significantly influence human health (Licata et al., 2004). The measurement of metal levels is helpful not only in ascertaining risk to human health but also in the assessment of environmental quality. Many workers have reported the presence of heavy metals in milk and other food products and attributed the presence of these heavy metals in milk and dairy products to exposure of lactating cows to environmental pollution, consumption of contaminated feed stuffs and water as well as the production process (Tuzen et al., 2008). These metals enter the human body mainly by two routes namely: inhalation and ingestion (Tripathi et al., 1997). Thus, information on the intake of heavy metals through food chain is important in assessing risk to human health. The objective of this study is to evaluate the nutritional quality and mineral composition of fermented milk (nono) sold in Kano, North-Western Nigeria

\section{MATERIALS AND METHODS \\ Sample collection}

Four hundred nono samples were purchased from 9 nono retailing markets located in the three (3) senatorial zones of the State. Each senatorial zone was represented by three markets, one in each of the three local governments. Proportionate sampling technique was adopted. Kano North senatorial zone was represented by Dawakin Tofa $(n=40)$, Kabo $(n=39)$ and Makoda $(n=39)$. Kano Central was represented by Warawa $(n=46)$, Gwale $(n=45)$ and Madobi $(n=45)$ while Kano South was represented by Sumaila $(n=49)$, Wudil $(n=49)$ and Gaya $(n=48)$. The sample collection and analysis were for a period of eighteen months, (October, 2016 to March, 2018). Hawked nono samples were collected fortnightly in sterile corked bottles and transported in cool box with ice to the Chemistry and Biochemistry laboratories of the Bayero University, Kano for the analyses.

\section{NUTRITIONAL ANALYSIS}

\section{(a) Determination of pH and Acidity}

The $\mathrm{pH}$ was determined according to the method of AOAC (2005). The glass electrode was pushed into the sample to about $3 / 4$ of the sample, then swirled for 5 seconds and allowed to become steady before taking reading on the Jenway- U.K $\mathrm{pH}$ meter. Acidity was determined by titration using the method of AOAC (2005). The content of nono and indicator was mixed by gentle shaking and $1 \mathrm{ml}$ of $0.1 \mathrm{~N}$ sodium hydroxide was added within 15 seconds from the burette. This was followed by drop mix addition of the $0.1 \mathrm{~N} \mathrm{NaOH}$ till a faint pink color, which persisted for 15 seconds appeared. The titre was read and expressed in percentage. The acidity of the samples was calculated by using the following equation:

Titratable acidity $(\%)=0.0090 \times$ volume of $\mathrm{NaOH}$ used $x 100$ / weight of the sample

\section{(b) Determination of Protein, Carbohydrate and Ash contents}

Crude protein content was analyzed for by the Microjedhal estimation of nitrogen, using a conversion factor of $\% \mathrm{~N} \times 6.25$. Carbohydrate was determined by the nitrogen free method as described by AOAC (2005). This was calculated as weight by difference between 100 and the summation of other proximate parameters as nitrogen free extract. Ash was determined by direct heating method as contained in AOAC (2005). The sample was burnt to ash in a muffle furnace for $3 \mathrm{hrs}$ at $550^{\circ} \mathrm{C}$. After ashing the crucible containing the ash was allowed to cool and then weighed.

\section{(c) Determination of moisture, fat and total solid contents}

The level of moisture was determined gravimetrically according to AOAC (2005) using a vacuum oven. The dish containing the sample was placed in an oven at $105^{\circ} \mathrm{C}$ for 3 hours, cooled in desiccator for 30 minutes and finally weighed. The fat content of the nono sample was determined gravimetrically according to the method of AOAC (2005). Briefly, $10 \mathrm{ml}$ sulphuric acid, $5 \mathrm{ml}$ sample and $5 \mathrm{ml}$ distilled water was measured into milk butyrometer. The neck of the butyrometer was firmly closed with the stopper and shaken in a stand and inverted twice during the process. The butyrometer was centrifuged (Centurion 4000 series-China) after mixing for a speed of $1100 \mathrm{rpm}$ for 4 minutes. The scale reading corresponding to the lowest part of the fat meniscus and to the surface of separation of the fat and the acid was read. Total solid was determined as described by AOAC (2005). Three grams of the nono sample was weighed into a dry glass Petri dish of a known weight. The total portion was pre-dried for 25 minutes on a steam bath and then dried for three hours at $100^{\circ} \mathrm{C}$ in forced draft air oven. The total solid sample was obtained as the weight of the dried sample residue. 
BAJOPAS Volume 12 Number 2, December, 2019

\section{(d) Determination of mineral element} content

Flame atomic absorption spectrophotometer analytical method was used to determine the mineral content as described by Belete et al. (2014). The amount $3.0 \mathrm{~mL}$ of each nono sample was transferred into $60 \mathrm{ml}$ digestion vessel and then optimized volumes of $6 \mathrm{ml}$ of $70 \%$ nitric acid and $1 \mathrm{ml}$ of $30 \%$ hydrogen peroxide were added and the mixture was shaken carefully and kept for 10 mins before closing the vessel. The samples were subjected to closed vessel microwave (LGJapan) digestion at the optimized microwave digestion program in the sequence of $50 \mathrm{~W}, 165^{\circ} \mathrm{C}$ $(10 \mathrm{~min}) ; 80 \mathrm{~W}, 190^{\circ} \mathrm{C}(20 \mathrm{~min}) ;$ and $0 \mathrm{~W}, 50^{\circ} \mathrm{C}(10$ min). After ashing, the sample was cooled to room temperature in a fume hood. The digest was diluted to $25 \mathrm{~mL}$ with deionized water and used for analysis. This solution was aspirated in to the flame of the instrument (SpectrophotometerAgient 200 Series Model No 240 FF) where it was heated to vaporize and atomize the minerals. A beam of radiation was passed through the atomized sample and the absorbance of radiation was measured at specific wavelengths $213-357$ $\mathrm{nm}$ corresponding to the mineral of interest. Information about the type and concentration of minerals present was obtained by measuring the location and intensity of the peaks in the absorption spectra.

\section{(e) Statistical analyses}

The data obtained from the research was subjected to analysis of variance (ANOVA) using one - way classification. Least significant difference (LSD) test was carried out at ( $p<$ 0.05 ) to determine whether there was significant difference between the means (Quinn and Keough, 2004)

\section{RESULTS AND DISCUSSION}

The result of the physical properties of the nono samples are presented in Table 1. The mean $\mathrm{pH}$ of nono samples from different markets ranged between 4.22 - 4.70. This result supports that obtained by Okonkwo (2011), El Bakri and El Zubeir (2009) but differ from 5.51- 6.29 reported by Adesokan et al. (2011) and 5.7 by Obi and Ikenebomeh (2007). The values of the pH obtained were within the standard limits. The low $\mathrm{pH}$ prevents the growth of most spoilage and pathogenic organisms (Varga, 2007). The titratable acidity ranged from $0.73-2.17 \%$ which is within the standard limits. The result obtained was higher than $0.08-0.13$ obtained by Egwaikhide et al. (2014). The high acidity explains why nono has a sour taste and may be due to the variation in duration of fermentation period and method of production. The result of nutritional composition of nono samples which is important in determining the properties of the milk is shown on Table 2. The mean protein content of the nono samples in this study ranged from $2.9-7.0 \%$. The values of protein obtained in most of the locations exceeded the permissible limit of $3 \%$ by FAO (2004). The results are also higher than the values reported by Obi and Ikenebomeh (2007) for nono in Benin-City but similar to values of $5.70-6.4 \%$ obtained by Dandare et al. (2014) in Sokoto. Milk proteins, particularly caseins, contain an appropriate amino acid, which contributes in formation of hormones and enzymes, which controls a variety of body functions such as growth and repair of the body cells as a high energy resource for the body (Mau et al., 1999). Results showed that the carbohydrate content of this study ranged from $4.6 \%$ to $8.2 \%$. These values are lower than those reported by Egwaikhide et al. (2014), Okeke et al. (2016) but higher than those reported by Uzeh et al. (2006). Carbohydrates are considered as fuel for all organisms, which contribute to about 55 $75 \%$ of energy required by the organisms (WHO, 2004). The mean ash content of the nono samples analyzed fell within $0.50-0.85 \%$ with Dawakin tofa having the highest $(0.85 \%)$ and the lowest being Makoda $(0.50 \%)$. These results are lower than $1.22-1.75 \%$ reported by Okeke et al. (2016) and comparable to $0.19-1.80 \%$ obtained by Egwaikhide et al. (2014). There is significant $(p \leq 0.05)$ difference between the market means of ash content. This difference may due to the pollution occurring in some market's environment. The significance of the ash content cannot be overemphasized as they account for the mineral constituents in a product sample (Gaman and Sherrigton, 1998). Ash is also the inorganic residue remaining after the water and organic matter have been removed by heating in the presence of oxidizing agent which provides a measure of the total amount of minerals present in a food. The moisture content obtained in this study ranged from $77.12-88.0 \%$ with the mean between 79.82 - $87.00 \%$. The mean value obtained in this study was comparable to moisture content of $86.99 \%$ reported by Yamamota et al. (2010) in Japan and $84.80-85.20 \%$ reported by Salau and Bolakale (2012) in Minna but slightly lower than $87.42 \%$ reported by Mirzadeh et al. (2010) in Lordegan Region of Iran. The moisture content obtained in this study is within FAO (2004) standards. Microbial stability is tied to moisture 
BAJOPAS Volume 12 Number 2, December, 2019

content. The tendency of microorganisms to grow in foods depends on their water content. Londhe et al. (2012) asserted that high moisture content is directly proportional to high water activity which in turn supports microbial growth consequently decreasing the shelf life of the milk sample. Conversely, low moisture content implies low water activity, which causes the reduction of microbial growth and consequently increasing the shelf life of milk and milk products. The mean fat content fell between $2.90 \%$ to $4.66 \%$. The Fat content obtained in this study was quiet low compared to fat content of $6.54 \%$ reported by Egwaikhide et al. (2014) in Kaduna but higher than $2.53 \%$ reported by Okeke et al. (2016) in Bida. The values for fat content obtained in this study are within the FAO (2004) standards of $3.5 \%$. The fat content of milk is of economic importance. It is a source of energy and contributes to the palatability of the diet. Milk is sold on the basis of its fat content but excess content of fat in food could constitute health risk (Pieter et al., 2007). The percentage total solid ranged between 8.6 to $12.43 \%$ which is similar to 12.8 - $13.2 \%$ reported by Eissa et al. (2011) in Sudan and comparable to 11.53 - $13.11 \%$ reported by Akinlade et al. (2017) in Oyo but higher than $6.3-9.5 \%$ reported by Egwaikhide et al. (2014) in Kaduna. This difference may be due to the rich fadama land in the study area with availability of grasses for the animals. Total Solid improves the texture of milk due to the protein functionality and gives body to the finished product.

From the result of mineral composition of nono samples in Table 3, it could be observed that the mineral content is a measure of the amount of specific inorganic components present within a food. The mean sodium concentration in this research ranged from $2.22-3.28 \mathrm{mg} / \mathrm{L}$. These values are higher than $0.1-0.2 \mathrm{mg} / \mathrm{L}$ reported by Okeke et al. (2016) but lower than the one reported by Fasae and Olusekan (2015). The measurement of metal levels is helpful not only in ascertaining risk to human health but also in the assessment of environmental quality (Binghila et al., 2008). In the human body, salt is needed to maintain the normal physiological activity, high intake of Sodium found in the composition of Salt leads especially to heart disease and high blood pressure. Sodium also, contributes to the buffering capacity of milk, the ionic strength and milk's osmotic pressure.

The potassium content ranged between $0.86 \mathrm{mg} / \mathrm{L}$ in Warawa to $2.65 \mathrm{mg} / \mathrm{L}$ in Sumaila. These values are higher than that reported by Akinlade et al. (2017) with $0.46-0.64 \mathrm{mg} / \mathrm{L}$ and Okeke et al. (2016) but agrees with that reported by Fasae and Olusekan (2015). Potassium is an electrolyte, used for maintaining fluid balance inside body cells and is essential to nerve transmission and muscle contraction. In milk, it helps to reduce the risk of high blood pressure. Potassium deficiency affects the collecting tubules of the kidney resulting in the inability to concentrate urine and also causes alterations of gastric secretions and intestinal motility (Soetan et al., 2010).

The magnesium content of the nono samples was found to be $3.95-6.30 \mathrm{mg} / \mathrm{L}$. These values are higher than $0.3 \mathrm{mg} / \mathrm{ml}$ reported by Okeke et al. (2016) in Bida and $0.16-0.19 \mathrm{mg} / \mathrm{ml}$ reported by Akinlade et al. (2017) in Oyo. Magnesium is required for the production of hormones that are important for the absorption of calcium from the gut and the mobilization of calcium from bones. Implication of the lower magnesium content from milk will lead to hyper irritability with convulsions, loss of equilibrium and trembling tetany (Adesina, 2012).

The average calcium concentration ranged from $35.0 \mathrm{mg} / \mathrm{L}$ in Gaya to $58.07 \mathrm{mg} / \mathrm{L}$ in Dawakin tofa. This value is higher than $(0.21-0.23 \mathrm{mg} / \mathrm{L})$ reported by Akinlade et al. (2017). The value of calcium obtained in this research is below the current dietary recommendation of $220-300 \mathrm{mg} / \mathrm{L}$ Calcium plays an important role in bones formation, muscle contraction and metabolism. It also helps slow the loss of bones due to aging.

The iron content of the nono samples were in the range of $1.23 \mathrm{~g} / \mathrm{L}$ in Dawakin tofa to $4.53 \mathrm{~g} / \mathrm{L}$ in Sumaila. This value is lower than $2.47-17.49$ $\mathrm{mg} / \mathrm{L}$ reported by Ogabiela et al. (2011). The iron concentration obtained is below dietary recommendation (WHO, 2004). Iron is an integral part of many proteins and enzymes that maintain good health. It is involved in oxygen transport, however excess iron may result in poisoning, even death (Chandra, 1990).

In the case of copper, the highest value was observed in Madobi with $1.28 \mathrm{~g} / \mathrm{L}$ while the lowest was observed in Sumaila with $0.61 \mathrm{~g} / \mathrm{L}$. This result is comparable to $1.31-1.56 \mathrm{mg} / \mathrm{L}$ 
BAJOPAS Volume 12 Number 2, December, 2019

Table 1: Physical Characteristics of Nono Samples

\begin{tabular}{lll}
\hline Markets & $\mathrm{pH}$ & Titratable acidity (\%) \\
\hline DTF & $4.24 \pm 0.04$ & $1.49 \pm 0.03$ \\
KBK & $4.22 \pm 0.05$ & $1.50 \pm 0.05$ \\
MKK & $4.36 \pm 0.07$ & $1.44 \pm 0.05$ \\
WRW & $4.42 \pm 0.06$ & $1.40 \pm 0.04$ \\
GWL & $4.35 \pm 0.05$ & $1.40 \pm 0.04$ \\
MDB & $4.36 \pm 0.05$ & $1.47 \pm 0.04$ \\
SML & $4.70 \pm 0.05$ & $1.44 \pm 0.04$ \\
WDL & $4.35 \pm 0.05$ & $1.49 \pm 0.04$ \\
GYA & $4.33 \pm 0.06$ & $1.34 \pm 0.04$ \\
WHO Standards (2004) & $\leq 4.5$ & $>0.6$ \\
\hline Key: Values are the mean of differ
\end{tabular}

Key: Values are the mean of different markets. No of samples: DTF = Dawakin tofa (40), KBK = Kabo (39), MKK = Makoda (39), WRW = Warawa (46 ), GWL=

Gwale (45), MDB = Madobi (45), SML = Sumaila (49), WDL = Wudil (49), GYA = Gaya (48). $\pm=$ S.E

Table 2: Mean Proximate Composition of the Nono Samples obtained from different markets at different Local Governments Areas of Kano

State

\begin{tabular}{|c|c|c|c|c|c|c|c|c|c|c|}
\hline \multirow[t]{2}{*}{ Parameter (\%) } & \multicolumn{8}{|c|}{ Markets } & \multirow[b]{2}{*}{$\begin{array}{l}\text { GYA } \\
(n=48)\end{array}$} & \multirow[b]{2}{*}{$\begin{array}{l}\text { Codex } \\
\text { standard } \\
(2004)\end{array}$} \\
\hline & $\begin{array}{l}\text { DTF } \\
(n=40)\end{array}$ & $\begin{array}{l}\text { KBK } \\
(n=39)\end{array}$ & $\begin{array}{l}\text { MKK } \\
(n=39)\end{array}$ & $\begin{array}{l}\text { WRW } \\
(n=46)\end{array}$ & $\begin{array}{l}\text { GWL } \\
(n=45)\end{array}$ & $\begin{array}{l}\text { MDB } \\
(n=45)\end{array}$ & $\begin{array}{l}S M L \\
(n=49)\end{array}$ & $\begin{array}{l}\text { WDL } \\
(n=49)\end{array}$ & & \\
\hline Protein (\%) & $3.40 \pm 0.11$ & $7.00 \pm 0.32$ & $2.90 \pm 0.05$ & $4.70 \pm 0.11$ & $5.20 \pm 0.05$ & $3.30 \pm 0.05$ & $5.00 \pm 0.11$ & $4.90 \pm 0.15$ & $3.80 \pm 0.15$ & 3 \\
\hline Carbohydrate & $5.57 \pm 0.04$ & $5.28 \pm 0.04$ & $6.2 \pm 0.15$ & $5.7 \pm 0.15$ & $4.6 \pm 0.05$ & $8.2 \pm 0.20$ & $7.5 \pm 0.17$ & $5.3 \pm 0.05$ & $6.8 \pm 0.11$ & 4 \\
\hline Ash & $0.85 \pm 0.03$ & $0.60 \pm 0.01$ & $0.50 \pm 0.01$ & $0.70 \pm 0.01$ & $0.66 \pm 0.01$ & $0.73 \pm 0.01$ & $0.82 \pm 0.02$ & $0.76 \pm 0.01$ & $0.62 \pm 0.01$ & 0.5 \\
\hline Moisture & $87.00 \pm 0.57$ & $83.05 \pm 0.56$ & $85.00 \pm 1.52$ & $79.82 \pm 0.55$ & $80.10 \pm 1.53$ & $84.60 \pm 0.40$ & $82.6 \pm 0.56$ & $86.2 \pm 0.50$ & $84.7 \pm 0.45$ & 87 \\
\hline Fat & $3.62 \pm 0.11$ & $3.90 \pm 0.10$ & $3.30 \pm 0.06$ & $4.10 \pm 0.10$ & $3.40 \pm 0.15$ & $4.20 \pm 0.13$ & $2.90 \pm 0.05$ & $4.66 \pm 0.08$ & $3.80 \pm 0.24$ & 3.5 \\
\hline Total Solid & $12.43 \pm 0.06$ & $8.6 \pm 0.15$ & $11.5 \pm 0.17$ & $10.8 \pm 0.20$ & $9 . .30 \pm 0.20$ & $9.4 \pm 0.20$ & $12.0 \pm 0.20$ & $11.4 \pm 0.15$ & $9.0 \pm 0.15$ & 12 \\
\hline
\end{tabular}

Key : $\quad \pm=$ Standard error

Table 3 Mineral Composition of Nono Samples obtained from different markets at different Local Governments Areas of Kano State Parameter

\begin{tabular}{|c|c|c|c|c|c|c|c|c|c|c|}
\hline$(\mathrm{mg} / \mathrm{l})$ & DTF $(n=40)$ & $\operatorname{KBK}(n=39)$ & MKK $(n=39)$ & WRW $(n=46)$ & GWL $(n=45)$ & $\operatorname{MDB}(n=45)$ & SML $(n=49)$ & WDL $(n=49)$ & GYA $(n=48)$ & $\begin{array}{l}\text { WHO } \\
(2004)\end{array}$ \\
\hline Sodium & $2.81 \pm 0.02$ & $3.28 \pm 0.03$ & $2.22 \pm 0.31$ & $2.60 \pm 0.05$ & $3.02 \pm 0.05$ & $2.50 \pm 0.02$ & $2.77 \pm 0.24$ & $3.10 \pm 0.21$ & $3.06 \pm 0.04$ & $90-130$ \\
\hline Potassium & $1.35 \pm 0.09$ & $1.00 \pm 0.03$ & $2.25 \pm 0.03$ & $0.86 \pm 0.11$ & $1.55 \pm 0.22$ & $2.00 \pm 0.07$ & $2.65 \pm 0.04$ & $1.58 \pm 0.07$ & $1.70 \pm 0.09$ & $410-550$ \\
\hline Magnesium & $4.97 \pm 0.15$ & $5.00 \pm 0.31$ & $4.65 \pm 0.08$ & $6.30 \pm 0.11$ & $4.30 \pm 0.11$ & $3.95 \pm 0.04$ & $5.45 \pm 0.08$ & $5.75 \pm 0.06$ & $4.60 \pm 0.08$ & $29-38$ \\
\hline Calcium & $58.07 \pm 0.44$ & $47.07 \pm 2.39$ & $55.02 \pm 1.06$ & $49.77 \pm 0.87$ & $50.66 \pm 1.03$ & $44.32 \pm 0.76$ & $39.85 \pm 0.83$ & $56.22 \pm 1.58$ & $35.00 \pm 1.62$ & $220-300$ \\
\hline Iron & $1.23 \pm 0.09$ & $3.42 \pm 0.13$ & $3.07 \pm 0.02$ & $2.77 \pm 0.07$ & $4.32 \pm 0.12$ & $2.86 \pm 0.07$ & $4.53 \pm 0.04$ & $2.75 \pm 0.06$ & $2.68 \pm 0.03$ & $350-720$ \\
\hline Copper & $0.64 \pm .05$ & $0.85 \pm 0.04$ & $0.84 \pm 0.04$ & $0.62 \pm 0.04$ & $0.87 \pm 0.02$ & $1.28 \pm 0.01$ & $0.61 \pm 0.03$ & $0.64 \pm 0.02$ & $0.71 \pm 0.01$ & $180-310$ \\
\hline Zinc & $0.58 \pm 0.03$ & $0.50 \pm 0.01$ & $0.62 \pm 0.02$ & $0.56 \pm 0.01$ & $0.60 \pm 0.01$ & $0.52 \pm 0.01$ & $0.64 \pm 0.01$ & $0.43 \pm 0.01$ & $0.48 \pm 0.01$ & $0.7-2.0$ \\
\hline Cadmium & $0.02 \pm 0.00$ & $0.00 \pm 0.00$ & $0.03 \pm 0.00$ & $0.01 \pm 0.00$ & $0.00 \pm 0.00$ & $0.02 \pm 0.00$ & $0.00 \pm 0.00$ & $0.03 \pm 0.00$ & $0.01 \pm 0.00$ & $<1$ \\
\hline Chromium & $1.58 \pm 0.02$ & $0.84 \pm 0.03$ & $0.89 \pm 0.04$ & $1.42 \pm 0.01$ & $1.36 \pm 0.02$ & $1.20 \pm 0.02$ & $0.94 \pm 0.05$ & $0.78 \pm 0.04$ & $1.40 \pm 0.02$ & $0.8-1.5$ \\
\hline Lead & $1.07 \pm 0.02$ & $0.80 \pm 0.02$ & $0.44 \pm 0.01$ & $0.29 \pm 0.01$ & $0.91 \pm 0.02$ & $0.55 \pm 0.03$ & $0.00 \pm 0.00$ & $0.22 \pm 0.01$ & $0.00 \pm 0.00$ & $2-5$ \\
\hline
\end{tabular}


BAJOPAS Volume 12 Number 2, December, 2019

reported by Akinlade et al. (2017). Copper is an essential trace element that plays a vital role in the physiology of animals for foetal growth and early post-natal development. Excess copper in the body leads to Wilson's disease which is characterized by deficiency of ceruloplasmin (Lawal et al., 2006). High exposure to copper also causes vomiting, bloody diarrhea, hypertension, and cardiovascular collapse (Abdallah, 2011).

The zinc content for the nono samples were in the range of $0.43-0.64 \mathrm{~g} / \mathrm{L}$ with the highest value observed in sumaila and the lowest observed in Wudil. These values are lower than the values reported by Belete et al. (2014) with (5.003 $6.218 \mathrm{mg} / \mathrm{L})$ but comparable to $(0.283$ $29.804 \mathrm{mg} / \mathrm{L}$ ) reported by Ogabiela et al. (2011). Zinc is a component of many enzymes and proteins, and is involved in gene regulation. It is an essential element but taking too much of it into the body through food, water, or dietary supplements can affect health. The recommended dietary allowance (RDAs) for zinc is $11 \mathrm{mg} /$ day for men and $8 \mathrm{mg} /$ day for women (WHO, 2004).

The highest cadmium content was $0.03 \mathrm{~g} / \mathrm{L}$ observed in Wudil while nil (0.00) was recorded in Kabo, Gwale and Sumaila. The result obtained for Cadmium in this study is similar to that reported by Belete et al. (2014) who reported nil but lower than the values $1.63 \mathrm{mg} / \mathrm{l}$ obtained by Ogabiela et al. (2011). The value of cadmium obtained in some markets exceeded the standard tolerance limit of $0.003 \mathrm{mg} / \mathrm{l}$. Cadmium is toxic and can be cumulative (Martins et al., 2000) and have adverse effects on human health. Chronic exposure can cause irreversible damage to the lungs and eventually death (Abdallah, 2011).

The values for chromium in this study (0.78 $1.58 \mathrm{mg} / \mathrm{L}$ ) is close to the report made by Belete et al. (2014) with $0.845-0.895 \mathrm{mg} / \mathrm{L}$ and lower than the values of Ogabiela et al. (2011) with 0.01 -

\section{REFERENCES}

Abdallah, M.I.M, (2011). Evaluation of some heavy metals residue in whole milk powder used at confectionary plant regarding the public health significance, Animal Research Institute, Agricultural Research Center, Giza Egypt. 16

Abdulkhaliq, A., Swaileh, K. M., Hussein, R. M and Matani, M (2012), Levels of metals (Cd, $\mathrm{Pb}, \mathrm{Cu}$ and $\mathrm{Fe}$ ) in cow's milk, dairy products and hen's eggs from the West Bank, Palestine. International Food Resource Journal 19(3); 1089-1094.
7.728. In high concentration chromium can cause poisoning but in low concentration are essential to maintain metabolic system (Qin et al., 2009). It can cause stomach upsets and ulcers, convulsions, kidney and liver damage, and even death. Tolerance limit of Chromium in milk is $0.3 \mathrm{mg} / \mathrm{kg}$ (Qin et al., 2009).

In this study, lead was not present in all the sampling sites, with concentrations ranging from $0.00 \mathrm{mg} / \mathrm{L}$ in Sumaila and Gaya to $1.07 \mathrm{mg} / \mathrm{L}$ observed in Dawakin tofa. This agrees with report made by Belete et al. (2014) that lead was present below detection limit and similar to $0.055 \mathrm{mg} / \mathrm{l}-1.264 \mathrm{mg} / \mathrm{l}$ reported by Ogabiela et al. (2011). The value of lead obtained in some markets did not fall within the standard tolerance limit of $0.02 \mathrm{mg} / \mathrm{l}$. Lead is toxic even at lower levels. Lead absorption constitutes serious risk to public health. It induces reduced cognitive development and intellectual performance in children, increased blood pressure, and cardiovascular diseases in adult as well as liver and kidney dysfunction (Abdallah, 2011).

\section{CONCLUSION}

In conclusion, the result of the study on nutritional composition showed that the values for protein, carbohydrate and fat content exceeded the FAO (2004) standard tolerance limit. However, the mineral analyses revealed that the values for the essential elements such as calcium, iron, magnesium, copper and zinc were below that of the current dietary recommendation by WHO,(2004). Metallic contaminants were also detected which are of public health concern. Studies on preservation methods of nono should be encouraged and undertaken by research organizations to maintain the nutritional quality of the nono milk and prevent exposure to contaminants.

Adesina, K. (2012) Effect of breed on the composition of cow milk under traditional management practices in Ado-Ekiti, Nigeria. Journal of Applied Science and Environmental Management 16(1): 55-59.

Adesokan, I.A., Odetoyinbo, B.B., Ekanola, Y.A., Avanrenren, R.E. and Fakorede, S (2011). Production of Nigerian nono using lactic starter cultures. Pakistan Journal of Nutrition. 10: 203-207.

Akinlade, J.A.,Alalade, J.A., Adewunmi, M.K., Adaramola, K.A and Tairu, H.M (2017). Nutritive assessment of milk from Fulani herds in the derived savanna zone of 
BAJOPAS Volume 12 Number 2, December, 2019 Nigeria. British Journal of Applied Science and Technology 19(2): 1-7

Association of Official Analytical Chemists: (AOAC, 2005) Official Methods of Analysis of AOAC International. $18^{\text {th }}$ Edition, Gaithersburg, MD, United States of America 8: 8-25

Belete, T., Hussen, A.Y. and Rao, V,H.(2014). Determination of concentrations of selected heavy metals in cow's milk: Bogena zone, Ethiopia. Journal of Health Science 4(5): $105-112$

Binghila, S., Simona D. G., Stanciu, A. and Soceanu, (2008). Determination of Major and Minor Elements in milk through ICPAES Environmental, Engineering and Management Journal: 6 ; 805-808.

Chandra, R.K.,(1990) Micro-nutrients and immune functions: An overview. Annual New York Academy of Science 587: 9-16.

Dandare, S.U., Gusau, A.M.and Ezeonwumelu, I.J. (2014). Comparative analysis of nutrient composition of milk from different breeds of cows European Journal of Applied and Scientific Research 3(2):33-36

Egwaikhide, P.A, Malu, P.S, Lawal, U, Adelagun, R.O, and Andrew, C. (2014). Physicochemical and microbiolgical analysis of fermented cow milk (Nono) consumed within Kaduna town, North West Nigeria. Food Science and Quality Management 29: 44-49.

Eissa, E.A, Babiker, E.E, and Yaqoub, A.E (2011). Physico-chemical, microbiological and sensory properties of Sudanese yoghurt (Zabadl) made from Goat's milk. Animal Science 51: $53-59$.

El Bakri, J.M. and El Zubeir, I.E.M (2009) Chemical and Microbiological evaluation of plain and fruit yoghurt in Khartoum State, Sudan. International Journal of Dairy Science, 4: 1-7.

Farid, S.M., Enani M.A. and Wajid S.A, (2004). Determination of trace elements in cow milk in Saudi Arabia, Journal of King Abdulazi University: Engineering .Science 15: (2): 131-140.

Fasae, O.A. and Olusesan, O.T.(2015). Quality assessment of fresh milk from traditionally managed Nigerian Bunaji and Bokolooji breeds of cattle. The Pacific Journal of Science and Technology. 16(1) 280-285.

Food and Agricultural Organization (2004). Manuals of food quality control. 8, FAO food and nutrition paper 14(8), Food analysis: quality, and adulteration and tests of identity. United Nations, Rome.

Gaman, P.M and Sherrington, K.B (1998). The Science of Food: An introduction to Food Science Nutrition and Microbiology. Pergamon Press Oxford. 196-215.

Lawal, A. O., Mohammed, S. S. and Damisa, D., (2006), Assessment of levels of copper, cadmium and lead in secretion of mammary gland of cows grazed on open fields .Science World Journal, 1(1): 7-10.

Licata, P., Trombetta, D., Cristani, M., Giofre, F., Martino, D., Calo, M and Naccari, F (2004), Levels of "toxic" and "essential" metals in samples of bovine milk from various dairy farms in Calabria, Italy. Environment International 30 ;1- 6.

Londhe, G., Pal, D. and Narender-Raju, P. LWT. (2012) Food Science and Technology. 47 (1): $117-125$

Martins, F.A.R., Sanchez, M.L.F. and Medel, A.S. (2000).Total determination of essential and toxic elements in milk whey by double focusing ICP-MS. Journal of Analytical Atomic Spectrometry.15:163-168.

Mau, J.I., Wu, K.T., Wu, Y.H. and Lin, Y.P. (1999). Non-volatile taste components of ear mushrooms, Journal of Agriculture and Food Chemistry. 46(11): 4583-4586

Mirzadeh, K., Masoudi, A., Chaji, M and Bojarpour, M. (2010). The composition of raw milk produced by some Dairy Farms in Lordegan Region of Iran. Journal of Animal and Veterinary Advances. 9(11): 1582 - 1583

Nasr, I. N., Sallam, A. A and Abd El-Khair, A. A (2007) Monitoring of certain pesticide residues and some heavy metals in fresh cow's milk at Gharbia governorate, Egypt Journal of Applied Science., 7(20); 30383044.

Obadina, A.O., Akinola, O.J., Shittu, T.A and Bakare, H.A (2013). Effect of Natural Fermentation on the Chemical and Nutritional Composition of Fermented Soymilk Nono. Nigerian Food Journa/31(2): 72-87.

Obi, C.N and Ikenebomeh, M.J, (2007). Studies on the Microbiology and Nutritional Qualities of a Nigerian Fermented Milk Product (Nono) International Journal of Dairy Science, 2: 95-99.

Ogabiela E. E., Udiba, U. U., Adesina, O. B., Hammuel, C., Ade-Ajayi, F. A., Yebpella, G. G., Mmereole U. J., Abdullahi, M., 
BAJOPAS Volume 12 Number 2, December, 2019

(2011), Assessment of metal levels in fresh milk from cows grazed around Challawa Industrial Estate of Kano, Nigeria., Journal of Basic and Applied Science Resources., 1(7); 533-538.

Okeke, K.S., Abdullahi, I.O., Makun, H.A. and Okeke, K.U. (2016). Physico-chemical and nutritional qualities of dairy cattle products. Global Journal of Life Sciences and Biological Research 2(2):8-13

Okonkwo, O.I. (2011). Microbiological analyses and safety evaluation of nono. A fermented milk product consumed in most parts of Northern Nigeria. International Journal of Dairy Science 6(3):181-189.

Pieter, W. Robert, J. and Badings, H.T (2007). Dairy Chemistry and physics, Wiley Inter Science $1^{\text {st }}$ Edition. Amazon New York. $440-467$

Qin, L. Q., Wang, X. P., Li, W., Tong, X., and Tong W. J. (2009), The minerals and heavy metals on cow's milk from China and Japan., Journal of Health Science., 55(2), 300-30.

Quinn, G. P and Keough, M. J (2004) Experimental Design and Data Analysis for Biologists Cambridge University Press. 560-573

Salau and Bolakale, R. (2012) Nutritional comparisons of milk from two cow milk specie and local preparations of soya milk drinks IOSR Journal of Applied Chemistry 2 (6): $41-44$.

Soetan, K.O, Olaiya, C.O and Oyewole O.E (2010). The importance of mineral elements for humans, domestic animals and plants: A review: African Journal of Food Science. 4(5): 200-222.

Tripathi, R.M., Raghunath, R. and Krishnamoorthy, T.M (1997) .Dietary intake of heavy metals in Bombay city, India. Science of Total Environment. 208: 49 - 159

Tuzen, M., Saracoglu, S and Soylak, M (2008). Evaluation of trace element's content of powdered beverages from Turkey. Journal of Food Nutrition Resource 47; 120-124.

Uzeh, R.E., Ohenhen, R.E and Rojagbokan, A.K. (2006). Microbiological and nutritional qualities of dairy products: nono and wara. Nature and Science, 4(3); 37-40

Valente, L. (2017). The origins of Milk: why was the first Cow milked in the first place. 13 Apr. 2017, Web. 02 Feb. 2019.

Varga, I. (2007). Microbiological quality of commercial dairy products, communicating current research and educational topics and trends in applied Microbiology, $A$. Méndez-Vilas (Ed.). pp. 487-494.

WHO (2004) World Health Organization / SDE/WSH/03.04/104/Rev/1. Manganese in drinking water: Background document for development of WHO Guidelines for Drinking-water Quality.

Yahaya, M. I., Ezor, G. C., Musa Y. F and Muhamad, S. Y, (2010). Analysis of heavy metals concentration in road side soils in Yauri, Nigeria. African Journal of pure and applied chemistry 4(3): 45-52

Yahuza, M.L. (2001). Small holder Dairy Production and Marketing Constraints in Nigeria In: Small holder Dairy Production and Marketing: Opportunities and Constraints, Rangneker, D. and W. Thorpe (Eds.). International Livestock Research Institute, Nairobi, Kenya

Yamamoto, A.,Mineshita, T. and Toyosakit, S. (2010). Viscosity of fresh milk, Public Medicine, 20(5): 623-634. 